Arq. Bras. Med. Vet. Zootec., v.68, n.3, p.571-578, 2016

\title{
Endoparasites of wild animals from three biomes in the State of Mato Grosso, Brazil
}

[Endoparasitas de animais silvestres de três biomas do Mato Grosso, Brasil]

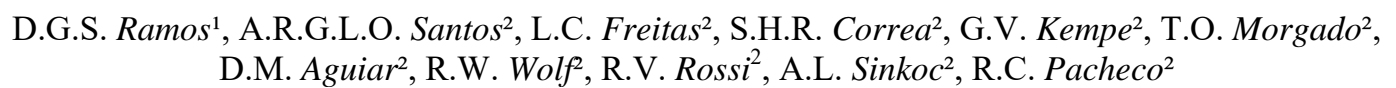

${ }^{1}$ Universidade Federal de Goiás - Jataí, GO

${ }^{2}$ Universidade Federal de Mato Grosso - Cuiabá, MT

\begin{abstract}
The population of wild animals is regulated by many biotic and abiotic factors, and parasites are a biotic factor that affects the dynamic and density of host populations. From 2002 to 2014, 62 wild animals from the biomes Pantanal, Amazon, and "Cerrado" (or Savanna), which died in attendance in the veterinary hospital or have been road-killed, underwent necropsy for parasitological examination. Overall, 36 species of parasites were identified from 24 host species. Among the parasites, the most prevalent order was Oxyurida (29.1\%), followed by Strongylida (20.9\%), Spirurida (19.4\%), Ascaridida (16.2\%), Pentastomida (3.2\%), Echinostomida (3.2\%), Gygantorhynchia (3.2\%), Rhabditida (1.6\%), Plagiorchiida $(1.6 \%)$, and Monilimorfida (1.6\%), especially nematodes, which have more biotic potential and is more easily adapted to the environment than other classes. The occurrence of endoparasites was observed more frequently in endothermic than ectothermic animals, and herein is reported eleven new host occurrences for endoparasites in wild animals. The study has contributed to the knowledge on the biodiversity of parasites in wild animals from three biomes in central-western Brazil.
\end{abstract}

Keywords: helminths, parasitism, Amazon, Cerrado, Pantanal

\section{RESUMO}

Populações de animais selvagens são reguladas por diversos fatores bióticos e abióticos, e parasitas são um fator biótico que afetam a dinâmica e a densidade de populações. De 2002 até 2014, 62 animais silvestres provenientes dos biomas Pantanal, Amazônia e Cerrado, que vieram a óbito no atendimento do hospital veterinário ou foram encontrados atropelados em rodovias, foram submetidos à necropsia parasitológica. Ao todo 36 espécies de parasitas foram identificadas em 24 espécies de hospedeiros. Entre os parasitas, a ordem mais prevalente foi Oxyurida (29,1\%), seguida por Strongylida (20,9\%), Spirurida (19,4\%), Ascaridida (16,2\%), Pentastomida (3,2\%), Echinostomida (3,2\%), Gygantorhynchia (3,2\%), Rhabditida (1,6\%), Plagiorchiida (1,6\%) e Monilimorfida (1,6\%), destacando-se os nematódeos, por seu maior potencial biótico e facilidade de adaptação ao meio do que as demais classes. A maior ocorrência de endoparasitas foi observada em animais endotérmicos que ectotérmicos, e este estudo registra onze novas ocorrências de hospedeiros para endoparasitas de animais selvagens. $O$ estudo contribui para o conhecimento da biodiversidade de parasitas em animais silvestres dos três biomas do Centro-Oeste do Brasil.

Palavras-chave: helmintos, parasitismo, Amazônia, Cerrado, Pantanal

\section{INTRODUCTION}

The population of wild animals is regulated by many biotic or abiotic factors, and parasites are a biotic factor that affects the dynamic and density

Recebido em 9 de fevereiro de 2015

Aceito em 4 de janeiro de 2016

E-mail: dgramos_vet@hotmail.com of host populations (Anderson and May, 1979). The main relationships between parasites and hosts are that parasites may: kill their hosts; interfere in feeding and reproduction; contribute to the host dispersion; or not show any effect (Borgsteede, 1996). In this sense, serious 
problems may arise if a parasite is introduced into a new environment where suitable hosts are available, which are fully susceptible to these parasites (Borgsteede, 1996). Furthermore, most wild parasite biology is fully or partially unexplained, and may often occur in domestic animals and humans, such as have reported for Spirometra mansonoides and Sphaerirostris erraticus in cats by Ramos et al. (2013), and for sparganosis (Spirometra spp.) in humans by Mentz et al. (2011). These reports show how helminths that have wild animals as hosts in their life cycle may occur in domestic animals and humans in anthropic areas.

The Amazon biome is comprised of the Amazon forest, which is the biggest tropical forest in the world, with great richness of flora and fauna (Ab'Saber, 1977). The Pantanal biome is the largest tropical wetland area in the world. Located in central South America, including Brazil, Bolivia and Paraguay, the Pantanal ecosystem is characterized by flooding and drying cycles, which causes a constant movement of animals, variations in flora, and landscape changes (Junk and Cunha, 2005). It has been considered a World Natural Heritage and World Biosphere Reserve by UNESCO. Its fauna and flora are similar to the Brazilian "Cerrado" (Brazilian Savanna) biome (adjacent biome), which is a tropical savanna with unique and distinct characteristics from other savannas, with dimensions that extend across the Brazilian central plateau (Oliveira and Marquis, 2002). Although these biomes contain large preserved areas, animals routinely pass by roads or access the anthropic regions that are close to them.

Considering few records about parasite helminths in vertebrate species from these biomes, this study aimed to identify endoparasites in wild animals from the Pantanal,
Amazon, and Cerrado biomes in the State of Mato Grosso, central-western Brazil.

\section{MATERIALS AND METHODS}

From 2002 to 2014, 62 wild animals from the Amazon (Alta Floresta, and Jauru municipalities), Cerrado (Chapada dos Guimarães and Cuiabá municipalities), and Pantanal (Poconé municipality) biomes (Fig. 1), that died in attendance in the veterinary hospital of the Federal University of Mato Grosso or were road-killed, were submitted to necropsy for parasitological examination. The esophagus, stomach, small intestine and large intestine were individually washed and filtered in $0.15 \mathrm{~mm}$ sieve, and examined in stereomicroscope under 10x magnification. The same procedure was performed with lungs, trachea, liver, heart, pancreas, kidneys, bladder, and the musculature (Ramos et al., 2013). All helminth parasites found were collected and processed according to Hoffman (1987). The identification was carried out following specific keys according to each taxonomic group: Anderson et al. (2009) and Gibbons (2010) for nematodes; and Bray et al. (2008) for trematodes. The specimens of Pentastomida have been clarified in Hoyer's medium and subsequently identified according to Riley et al. (1990). Revision works of Machado Filho (1950) were used to identify Acanthocephalans. The Ethic Committee on Animal Research of the Universidade Federal de Mato Grosso (UFMT) approved this study under protocol $n^{\circ} 23108.043095 / 13-6$, and the Instituto Brasileiro do Meio Ambiente e dos Recursos Naturais Renováveis (IBAMA) authorized the procedures for primates under the protocol $\mathrm{n}^{\circ}$ 6364-1. Road-killed animals were cordially donated by IBAMA to the Veterinary Hospital of the Federal University of Mato Grosso. 


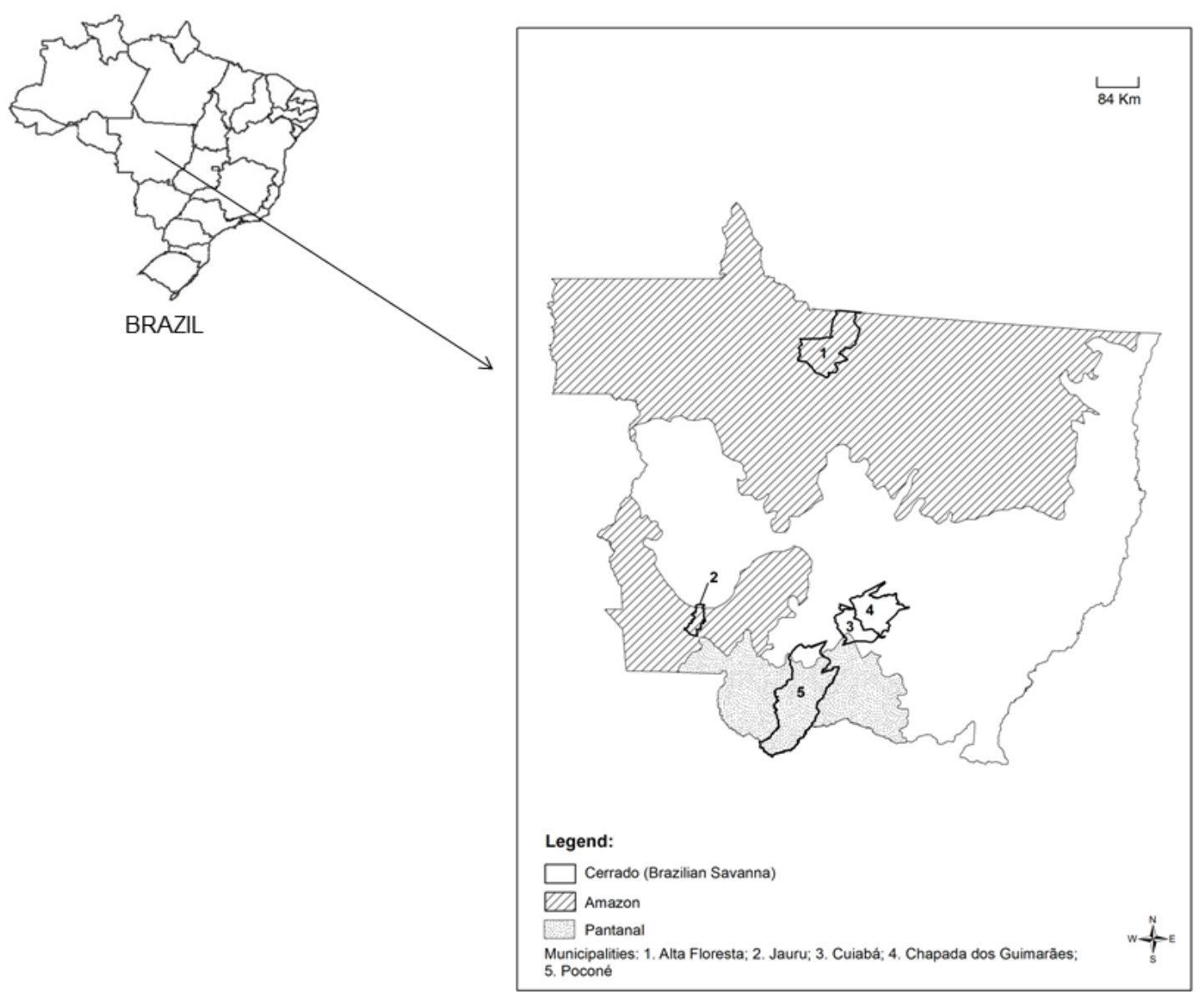

Figure 1. Map of the biomes of Mato Grosso State, Brazil, and location of Alta Floresta, Jauru, Cuiabá, Chapada dos Guimarães and Poconé municipalities in their respective biomes.

\section{RESULTS}

Overall, 36 species of parasites were identified from 24 host species and are listed in Table 1, according to hosts, animal's common name, number of parasitized animals, location of endoparasites, taxonomic identification, and location. Among parasites, the most prevalent order was Oxyurida (29.1\%), followed by Strongylida $\quad(20.9 \%)$, Spirurida $\quad(19.4 \%)$, Ascaridida (16.2\%), Pentastomida (3.2\%), Echinostomida (3.2\%), Gygantorhynchia (3.2\%), Rhabditida (1.6\%), Plagiorchiida (1.6\%), and Monilimorfida (1.6\%). Considering the animal regulation of body temperature, 49 endothermic animals were parasitized (79\%) against 13 ectothermic animals (21\%).

Among animals sampled, five were from captivity, and of these, three (Chrysocyon brachyurus, Panthera onca, and Tamandua tetradactyla) showed occurrence of parasites (Ancylostoma caninum, Toxascaris leonina, and Physaloptera praeputialis), commonly found in domestic animals. Furthermore, this study provided eleven new occurrences of endoparasites in wild animals as showed in Table 1. 


\section{Ramos et al.}

Table 1. Endoparasites found in wild vertebrates examined in the present study. Parasite specimens are deposited in the Laboratory of Parasitic Diseases, Veterinary Hospital, Federal University of Mato Grosso, Cuiabá, Mato Grosso State, Brazil.

\begin{tabular}{|c|c|c|c|c|c|c|c|}
\hline Hosts & $\begin{array}{l}\text { Common } \\
\text { Name }\end{array}$ & $\mathrm{N}$ & Organs & $\begin{array}{l}\text { Endoparasites } \\
\text { Identification }\end{array}$ & Parasite Order & Location & $\begin{array}{c}\text { Parasite } \\
\text { Description } \\
\text { Reference }\end{array}$ \\
\hline \multicolumn{8}{|l|}{ Anphibians } \\
\hline $\begin{array}{l}\text { Rhinella } \\
\text { schneideri }\end{array}$ & Cururu Toad & 1 & Lungs & Rhabdias sp. & Rhabditida & Poconé & $\begin{array}{l}\text { Stiles and } \\
\text { Hassall, } 1906\end{array}$ \\
\hline \multicolumn{8}{|l|}{ Reptiles } \\
\hline \multirow[t]{4}{*}{ Boa constrictor } & Boa & 1 & $\begin{array}{l}\text { Celomatic } \\
\text { Cavity }\end{array}$ & $\begin{array}{l}\text { Hastospiculum } \\
\text { onchocercum }\end{array}$ & Spirurida & $\begin{array}{l}\text { Chapada dos } \\
\text { Guimarães } \\
\text { Chapada dos }\end{array}$ & Chitwood, 1932 \\
\hline & & 3 & Small Intestine & $\begin{array}{l}\text { Kalicephalus } \\
\text { subulatus }\end{array}$ & Strongylida & $\begin{array}{l}\text { Guimarães; } \\
\text { Cuiabá; } \\
\text { Poconé }\end{array}$ & Molin, 1861 \\
\hline & & 1 & $\begin{array}{l}\text { Celomatic } \\
\text { Cavity }\end{array}$ & Ophidascaris spp. & Ascaridida & Poconé & Baylis, 1920 \\
\hline & & 1 & Lung & $\begin{array}{l}\text { Sebekia } \\
\text { oxicephala*** }\end{array}$ & Pentastomida & Poconé & Diesing, 1835 \\
\hline \multirow[t]{2}{*}{ Eunectes murinus } & Anaconda & 1 & Stomach & $\begin{array}{l}\text { Physaloptera } \\
\text { liophis*** }\end{array}$ & Spirurida & Poconé & $\begin{array}{l}\text { Vicente and } \\
\text { Santos, } 1974\end{array}$ \\
\hline & & 1 & Lung & $\begin{array}{l}\text { Sebekia } \\
\text { oxicephala*** }\end{array}$ & Pentastomida & Poconé & Diesing, 1835 \\
\hline $\begin{array}{l}\text { Gerochelone } \\
\text { carbonaria* }\end{array}$ & - & 1 & Small Intestine & Labiduris gulosa & Ascaridida & Cuiabá & Rudolphi, 1819 \\
\hline Iguana iguana & $\begin{array}{l}\text { Green } \\
\text { Iguana }\end{array}$ & 2 & Large Intestine & Ozolaimus cirratus & Oxyurida & $\begin{array}{l}\text { Chapada dos } \\
\text { Guimarães; } \\
\text { Cuiabá }\end{array}$ & Linstow, 1906 \\
\hline Tupinambis sp. & $\begin{array}{l}\text { Crocodile } \\
\text { Tegu }\end{array}$ & 1 & Stomach & $\begin{array}{l}\text { Physaloptera } \\
\text { retusa }\end{array}$ & Spirurida & $\begin{array}{l}\text { Chapada dos } \\
\text { Guimarães }\end{array}$ & Rudolphi, 1819 \\
\hline \multicolumn{8}{|l|}{ Birds } \\
\hline Crotophaga ani & $\begin{array}{l}\text { Smooth- } \\
\text { billed Ani }\end{array}$ & 1 & Small Intestine & $\begin{array}{l}\text { Cyrnea } \\
\text { semilunaris*** }\end{array}$ & Spirurida & Poconé & Molin, 1860 \\
\hline Pavo cristatus & Peafowl & 1 & Large Intestine & Heterakis nattereri & Strongylida & $\begin{array}{l}\text { Chapada dos } \\
\text { Guimarães }\end{array}$ & Travassos, 1923 \\
\hline \multirow[t]{3}{*}{ Rhea americana } & Greater Rhea & 1 & Large Intestine & $\begin{array}{l}\text { Deletrocephalus } \\
\text { spp. }\end{array}$ & Strongylida & Cuiabá & Diesing, 1851 \\
\hline & & 1 & $\begin{array}{l}\text { Celomatic } \\
\text { Cavity }\end{array}$ & $\begin{array}{l}\text { Dicheilonema } \\
\text { rheae }\end{array}$ & Spirurida & $\begin{array}{l}\text { Chapada dos } \\
\text { Guimarães }\end{array}$ & Owen, 1843 \\
\hline & & 1 & Proventriculus & $\begin{array}{l}\text { Odontospirura } \\
\text { zschokkei }\end{array}$ & Spirurida & Poconé & $\begin{array}{l}\text { Railliet and } \\
\text { Henry, } 1911\end{array}$ \\
\hline \multicolumn{8}{|l|}{ Mammals } \\
\hline Ateles chamek ${ }^{1}$ & $\begin{array}{l}\text { Black Spider } \\
\text { Monkey }\end{array}$ & 1 & Large Intestine & Trypanoxyuris spp. & Oxyurida & Alta Floresta & Vevers, 1923 \\
\hline Callicebus moloch & Titi Monkey & 1 & Small Intestine & $\begin{array}{l}\text { Prosthenorchis } \\
\text { sigmoides*** }\end{array}$ & Gigantorhynchia & Alta Floresta & $\begin{array}{l}\text { Machado Filho, } \\
1950\end{array}$ \\
\hline
\end{tabular}


Endoparasites of wild...

\begin{tabular}{|c|c|c|c|c|c|c|c|}
\hline $\begin{array}{l}\text { Chrysocyon } \\
\text { brachyurus } *, 2\end{array}$ & Maned Wolf & 1 & Small Intestine & $\begin{array}{l}\text { Ancylostoma } \\
\text { caninum }\end{array}$ & Strongylida & Cuiabá & Ercolani, 1859 \\
\hline $\begin{array}{l}\text { Dasyprocta } \\
\text { azarae }\end{array}$ & $\begin{array}{l}\text { Azara's } \\
\text { Agouti }\end{array}$ & 1 & Large intestine & $\begin{array}{l}\text { Eucyathostomum } \\
\text { copulatum }\end{array}$ & Strongylida & $\begin{array}{l}\text { Chapada dos } \\
\text { Guimarães }\end{array}$ & Molin, 1861 \\
\hline $\begin{array}{l}\text { Didelphis } \\
\text { albiventris }\end{array}$ & $\begin{array}{l}\text { White-eared } \\
\text { Opossum }\end{array}$ & 2 & Small Intestine & Cruzia tentaculata & Oxyurida & Cuiabá & Rudolphi, 1819 \\
\hline \multirow{3}{*}{$\begin{array}{l}\text { Didelphis } \\
\text { marsupialis }\end{array}$} & \multirow{3}{*}{$\begin{array}{l}\text { Black-eared } \\
\text { Opossum }\end{array}$} & 1 & Liver & Zonorchis spp. & Plagiorchiida & Cuiabá & Travassos, 1944 \\
\hline & & 2 & Small Intestine & Aspidodera spp. & Ascaridida & $\begin{array}{l}\text { Cuiabá; } \\
\text { Poconé }\end{array}$ & $\begin{array}{l}\text { Railliet and } \\
\text { Henry, } 1912\end{array}$ \\
\hline & & 1 & Small Intestine & Cruzia tentaculata & Oxyurida & Poconé & Rudolphi, 1819 \\
\hline $\begin{array}{l}\text { Herpailurus } \\
\text { yagouaroundi }{ }^{2}\end{array}$ & Jaguarundi & 1 & Lung & $\begin{array}{l}\text { Metathelazia } \\
\text { spp.*** }\end{array}$ & Spirurida & Poconé & Skinker, 1931 \\
\hline \multirow[t]{2}{*}{$\begin{array}{l}\text { Hydrochoerus } \\
\text { hydrochaeris }\end{array}$} & \multirow[t]{2}{*}{ Capybara } & 1 & Large Intestine & $\begin{array}{l}\text { Taxorchis } \\
\text { schistocotyle }\end{array}$ & Echinostomida & Poconé & $\begin{array}{l}\text { Fischoeder, } \\
1901\end{array}$ \\
\hline & & 3 & Large Intestine & $\begin{array}{l}\text { Protozoophaga } \\
\text { obesa }\end{array}$ & Oxyurida & $\begin{array}{l}\text { Chapada dos } \\
\text { Guimarães }\end{array}$ & Diesing, 1851 \\
\hline \multirow[t]{2}{*}{ Mico emiliae } & \multirow[t]{2}{*}{$\begin{array}{l}\text { Snethlage's } \\
\text { Marmoset }\end{array}$} & 2 & Small Intestine & Primasubulura spp. & Ascaridida & Alta Floresta & Inglis, 1958 \\
\hline & & 4 & Large Intestine & $\begin{array}{l}\text { Trypanoxyuris } \\
\text { callithricis*** }\end{array}$ & Oxyurida & Alta Floresta & Solomon, 1933 \\
\hline Mico melanurus** & $\begin{array}{l}\text { Black-tailed } \\
\text { Marmoset }\end{array}$ & 4 & Large Intestine & $\begin{array}{l}\text { Trypanoxyuris } \\
\text { callithricis }\end{array}$ & Oxyurida & $\begin{array}{l}\text { Chapada dos } \\
\text { Guimarães; } \\
\text { Cuiabá; } \\
\text { Poconé }\end{array}$ & Solomon, 1933 \\
\hline & & 3 & Small Intestine & Primasubulura spp. & Ascaridida & Cuiabá & Inglis, 1958 \\
\hline $\begin{array}{l}\text { Myrmecophaga } \\
\text { tridactyla }^{1}\end{array}$ & $\begin{array}{l}\text { Giant } \\
\text { Anteater }\end{array}$ & 1 & Small Intestine & $\begin{array}{l}\text { Moniliformis } \\
\text { moniliformis*** }\end{array}$ & Monilimorfida & $\begin{array}{l}\text { Chapada dos } \\
\text { Guimarães }\end{array}$ & Bremser, 1811 \\
\hline Panthera onca ${ }^{*, 2}$ & Jaguar & 1 & Small Intestine & Toxascaris leonina & Ascaridida & Cuiabá & Linstow, 1902 \\
\hline \multirow[t]{7}{*}{ Sapajus apella } & \multirow[t]{7}{*}{$\begin{array}{l}\text { Tufted } \\
\text { Capuchin }\end{array}$} & 2 & Lungs & Filariopsis barretoi & Strongylida & Alta Floresta & Travassos, 1921 \\
\hline & & 1 & Small Intestine & Molineus torulosus & Strongylida & Alta Floresta & Molin, 1861 \\
\hline & & 3 & Stomach & Physaloptera spp. & Spirurida & Alta Floresta & Rudolphi, 1819 \\
\hline & & 1 & Small Intestine & $\begin{array}{l}\text { Prosthenorchis } \\
\text { sigmoides*** }\end{array}$ & Gigantorhynchia & Alta Floresta & $\begin{array}{l}\text { Machado Filho, } \\
1950\end{array}$ \\
\hline & & 1 & Small Intestine & Spirura spp. & Spirurida & Alta Floresta & Blanchard, 1849 \\
\hline & & 1 & Small Intestine & $\begin{array}{l}\text { Trichostrongylus } \\
\text { cesticillus }\end{array}$ & Strongylida & Alta Floresta & Molin, 1861 \\
\hline & & 1 & Large Intestine & $\begin{array}{l}\text { Trypanoxyuris } \\
\text { callithricis**** }\end{array}$ & Oxyurida & Alta Floresta & Solomon, 1933 \\
\hline $\begin{array}{l}\text { Tamandua } \\
\text { tetradactyla* }\end{array}$ & $\begin{array}{l}\text { Southern } \\
\text { Tamandua }\end{array}$ & 1 & Stomach & $\begin{array}{l}\text { Physaloptera } \\
\text { praeputialis*** }\end{array}$ & Spirurida & Cuiabá & Linstow, 1889 \\
\hline \multirow[t]{2}{*}{ Tapirus terrestris ${ }^{1}$} & \multirow[t]{2}{*}{$\begin{array}{l}\text { Lowland } \\
\text { Tapir }\end{array}$} & 2 & Large Intestine & Neomurshidia spp. & Strongylida & $\begin{array}{l}\text { Jauru; } \\
\text { Poconé }\end{array}$ & Chabaud, 1957 \\
\hline & & 1 & Large Intestine & $\begin{array}{l}\text { Cladorchis } \\
\text { pyriformis }\end{array}$ & Echinostomida & Jauru & Diesing, 1838 \\
\hline
\end{tabular}




\section{DISCUSSION}

Considering identification of three of the four major groups of helminths (nematodes, trematodes and acanthocephalans), as well as arthropods species (pentastomida - Sebekia oxycephala), this study showed diversity of endoparasites of wild animals commonly found in the Amazon, Pantanal, and Cerrado biomes. Between 1828 and 1829, Diesing and Rudolphi have described parasites of several species of hosts from the Pantanal region and Cuiabá municipality, State of Mato Grosso, which were deposited in Berlin and Vienna museums (Rego and Vicente, 1988). These and the samples collected by Travassos from 1922 to 1948, resulted practically in all parasitic fauna currently known that occurs in wild animals from Pantanal (Rego and Vicente, 1988). After these reports, there are few records of wild animals' helminths from Pantanal, and from other biomes of the State (Costa and Catto, 1994; Zattermann et al., 2005; Lopes Torres et al., 2009; Simões et al., 2010; Campião et al., 2014). The spectrum of parasitic disease in wild animals has great importance in human and veterinary medicine, and the knowledge about their parasites is essential since biotic and abiotic components may interfere in the dynamics and structure of parasite communities, as well as in the parasite communities of humans and domestic animals (Esch et al., 1990). The occurrence of Trypanoxyuris callithricis in primates of genera Sapajus and Mico, may be associated to the fact that $T$. callithricis has been adapted to parasitize infra communities of primates in Amazonia and Cerrado biomes, since it is commonly observed infecting Callithrix jacchus, and other species of the same gender (Vicente et al., 1997). This possible adaptation described above has also been observed in Prosthenorchis sigmoides, which was described parasitizing the small intestine of C. jacchus (Machado Filho, 1950), and herein it was detected in Callicebus moloch and Sapajus apella.

It is possible that the dynamics of infection may have possibly been modified in animals raised in captivity. Reports of Toxascaris leonina and Ancylostoma caninum detected in Panthera onca and Chrysocyon brachyurus, respectively, are scarce (Vincent et al., 1997). However, T. leonina has been found in carnivores in captivity, which is possibly associated with its short life cycle, and may be easily concluded in captivity compared with other parasites such as Toxocara spp. (Bowman, 2009). In contrast, Physaloptera praeputialis, which is a stomach parasite of mammals of the Carnivora order, especially domestic animals such as cats and dogs (Vicente et al., 1997), was reported for the first time in Tamandua tetradactyla. Other species of Physaloptera, such as $P$. magnipapilla and $P$. papillotruncata, have already been described parasitizing Myrmecophaga tridactyla and $T$. tetradactyla, respectively (Vicente et al., 1997). The occurrence of these parasites commonly described in domestic animals may be associated to their presence close to the wild animal's captivities, as observed in animals raised in the zoo at the Federal University of Mato Grosso.

Moniliformis moniliformis detected in the giant anteater ( $M$. tridactyla) has already been described in humans (Salehabadi et al., 2008), and domestic animals (Asato et al., 1986). The acanthocephalan species usually found in rodents uses an arthropod as the intermediate host (Gadale et al., 1989), so the giant anteaters may act as definitive hosts by consuming infected intermediate hosts (cockroach and ants) during feeding. Also concerning endothermic hosts, the occurrence of Cyrnea semilunaris in Crotophaga ani is described for the first time. Metathelazia sp. has already been described in Puma concolor (Vicente et al., 1997), but its occurrence in Herpailurus yagouarandi is herein described for the first time

The occurrence of endoparasites was mostly observed in endothermic animals $(79 \%)$. Esch et al. (1990) highlighted that the parasite communities of endothermic animals are higher due to greater movement and digestive complexity in these species, and to greater exposure to parasites with direct cycle and active penetration in ectothermic hosts.

Regarding the ectothermic animals, the genus Physaloptera is commonly observed parasitizing the stomach of their definitive hosts, which includes the Liophis miliaris snake as described by Vicente et al. (1993). However, this is the first occurrence of Physaloptera liophis in Eunectes murinus. Pentastomid species of the family Sebekidae are known to parasite fishes, using turtles and caimans as definitive hosts (Riley, 1986). Brito et al. (2012) have described 
the parasitism of Sebekia oxycephala in lung, stomach and intestine of Cayman yacare, but there are no records of this Pentastomid species in Pantanal snakes, such as Boa constrictor and Eunectes murinus as observed.

Our study contributes to knowledge of parasites in wild animals from Amazon, Pantanal, and Cerrado due to the importance of these biomes, its biodiversity and the increasing anthropic action and possible changes in the dynamics of transmission of helminths in wildlife, especially considering the scarce information about these relationships evidenced by the new host occurrences of parasites herein described. Finally, the occurrence of helminths in animals at risk of extinction showed how the knowledge of wild parasitism, so important for the management and conservation of species, needs to be increased and developed.

\section{ACKNOWLEDGMENTS}

To the Instituto Brasileiro do Meio Ambiente e dos Recursos Naturais Renováveis (IBAMA); Coordenação de Aperfeiçoamento de Pessoal de Nível Superior (CAPES) for the financial support; to Conselho Nacional de Desenvolvimento Científico e Tecnológico (CNPq) for the scholarships of D. M. Aguiar, and R.C. Pacheco; Fundação de Amparo à Pesquisa do Estado de Mato Grosso (FAPEMAT); Laboratório de Patologia Veterinária (LPV)-UFMT.

\section{REFERENCES}

AB'SABER, A.N. Os domínios morfoclimáticos na América do Sul: primeira aproximação. Geomorfologia, v.51, p.1-23, 1977.

ANDERSON, R.C.; CHABAUD, A.G.; WILMOTT, S. Keys to the nematode parasites of vertebrates: archival volumes. Cambridge: Cabi, 2009. 463p.

ANDERSON, R.M.; MAY, R.M. Population biology of infectious diseases. Part I. Nature, v.280, p.361-367, 1979.

ASATO, R.; HASEGAWA, H.; KUNIYOSHI, S.; HIGA, T. Prevalence of helminthic infections in cats on Okinawa Island Japan. Jap. J. Parasitol., v.35, p.209-214, 1986.
BORGSTEEDE, F.H.M. The effect of parasites on wildlife. Vet. Q., v.18, supl.3, p.138-140, 1996.

BOWMAN, D.D. Georgis' parasitology for veterinarians. 9.ed. St. Louis: Saunders Elsevier, 2009. $451 \mathrm{p}$.

BRAY, R.A.; GIBSON, D.I.; JONES, A. Keys to the Trematoda. Cambridge: Cabi, 2008. 3v., $824 \mathrm{p}$.

BRITO, S.V.; ALMEIDA, W.O; ANJOS, L.A.; SILVA, R.J. New host records of Brazilian pentastomid species. Braz. J. Biol., v.72, p.393396, 2012.

CAMPIÃO, K.M.; SILVA, R.J.; FERREIRA, V.L. Helminth parasite communities of allopatric populations of the frog Leptodactylus podicipinus from Pantanal, Brazil. J. Helminthol., v.88, p.13-19, 2014.

COSTA, C.A.; CATTO, J.B. Helminth parasites of capybaras (Hydrochaeris hydrochaeris) on sub-region of Nhecolândia, Pantanal, Mato Grosso do Sul. Rev. Bras. Biol., v.54, p.39-48, 1994.

ESCH, G.; BUSH, A.; AHO, J. Parasite comunities: pattern and process. London: Chapman and Hall, 1990. 335p.

GADALE, O.I.; CAPELLI, G.; ALI, A.A.; POGLAYEN, G. Intestinal helminths of cats. First reports in Somalia. Boll. Sci. Fac. Zootech. Vet. Univ. Naz. Somalia, 1989. p.8-24.

GIBBONS, L.M. Keys to the nematode parasites of vertebrates: supplementary volume. Cambridge: Cabi; 2010. 416p.

HOFFMAN, R.P. Diagnóstico de parasitismo veterinário. Porto Alegre: Sulina; 1987. 156p.

IUCN red list of threatened species. Version 2014.3. 2014. Available in: $<$ http://www.iucnredlist.org $>$. Accessed in: 17 november 2014.

JUNK, W.J.; CUNHA, C.N. Pantanal: a large South American wetland at a crossroads. Eco. Engineering, v.24, p.391-401, 2005.

LISTAS das espécies da fauna brasileira ameaçadas de extinção. 2014. Available in: $<$ http://www.icmbio.gov.br/portal/biodiversidade /fauna-brasileira/lista-de-especies.html>.

Accessed in: 19 December 2014. 
LOPES TORRES, E.J.; MALDONADO, A. Jr.; LANFREDI, R.M. Spirurids from Gracilinanus agilis (Marsupialia: Didelphidae) in Brazilian Pantanal wetlands with a new species of Physaloptera (Nematoda: Spirurida). Vet. Parasitol., v.163, p.87-92 2009.

MACHADO FILHO, D.A. Revisão do gênero Prosthenorchis Travassos, 1915 (Acanthocephala). Mem. Inst. Oswaldo Cruz, v.48, p.495-544, 1950.

MENTZ, M.B.; PROCIANOY, F.; MAESTRI, M.K.; ROTT, M.B. Case report human ocular sparganosis in southern Brazil. Rev. Inst. Med. Trop. São Paulo, v.53, p.51-53, 2011.

OLIVEIRA, P.S.; MARQUIS, R.J. The Cerrados of Brazil: ecology and natural history of a neotropical savanna. New York: Columbia University Press, 2002. 398p.

RAMOS, D.G.S.; SCHEREMETA, R.G.A.C.; OLIVEIRA, A.C.S. et al. Survey of helminth parasites of cats from metropolitan area of Cuiabá, Mato Grosso, Brazil. Rev. Bras. Parasitol. Vet., v.22, p.201-206, 2013.

REGO, A.A.; VICENTE, J.J. Excursão científica ao Pantanal, estado de Mato grosso para coleta de helmintos. Ciênc. Cult., v.40, p.65-68, 1988.

RILEY, J.; SPRATT, D.M.; WINCH, J.M. A revision of the genus Sebekia Sambon, 1922 (Pentastomida) from crocodilians with descriptions of five new species. Syst. Parasitol., v.16, p.1-25, 1990.
RILEY, J. The biology of pentastomids. Adv. Parasitol., v.25, p.45-128, 1986.

SALEHABADI, A.; MOWLAVI, G.R.; SADJJADI, S.M. Human infection with Moniliformis moniliformis (Bremser, 1811) (Travassos, 1915) in Iran: Another case report after decades. Vector Borne Zoon. Dis., v.8, p.101-103, 2008.

SIMÕES, R.; GENTILE, R.; RADEMAKER, V. et al. Variation in the helminth community structure of Thrichomys pachyurus (Rodentia: Echimyidae) in two sub-regions of the Brazilian Pantanal: the effects of land use and seasonality. J. Helminthol., v.84, p.266-275, 2010.

VICENTE, J.J.; RODRIGUES, H.O.; GOMES, D.C.; PINTO, R.M. Nematoides do Brasil. Parte III: Nematóides de mamíferos. Rev. Bras. Zool., v.10, p.19-168, 1993.

VICENTE, J.J.; RODRIGUES, H.O.; GOMES, D.C.; PINTO, R.M. Nematóides do Brasil. Parte V: Nematoides de mamíferos. Rev. Bras. Zool., v.14, supl.1, p.1-452, 1997.

ZATTERMANN, C.D.; NASCIMENTO, A.A.; TEBALDI, J.A.; SZABÓ, M.J. Observations on helminth infections of free-living and captive rheas (Rhea americana) in Brazil. Vet. Parasitol., v.129, p.169-172, 2005. 